\title{
Catchment conceptualisation for examining applicability of chloride mass balance method in an area with historical forest clearance
}

\author{
H. Guan ${ }^{1,2}$, A. J. Love ${ }^{1,2,3}$, C. T. Simmons ${ }^{1,2}$, J. Hutson ${ }^{1,2}$, and Z. Ding ${ }^{1,4}$ \\ ${ }^{1}$ School of the Environment, Flinders University, Australia \\ ${ }^{2}$ National Centre for Groundwater Research and Training, Australia \\ ${ }^{3}$ Department of Water, Land and Biodiversity Conservation, South Australia \\ ${ }^{4}$ College of Earth and Environmental Science, Lanzhou University, China
}

Received: 9 September 2009 - Published in Hydrol. Earth Syst. Sci. Discuss.: 17 November 2009

Revised: 16 June 2010 - Accepted: 4 July 2010 - Published: 13 July 2010

\begin{abstract}
Of the various approaches for estimating groundwater recharge, the chloride mass balance $(\mathrm{CMB})$ method is one of the most frequently used, especially for arid and semiarid regions. Widespread native vegetation clearance, common in many areas globally, has changed the land surface boundary condition, posing the question as to whether the current system has reached new chloride equilibrium, required for a CMB application. Although a one-dimensional $\mathrm{CMB}$ can be applied at a point where the water and chloride fluxes are locally in steady state, the CMB method is usually applied at a catchment scale owing to significant lateral flows in mountains. The applicability of the CMB method to several conceptual catchment types of various chloride equilibrium conditions is examined. The conceptualisation, combined with some local climate conditions, is shown to be useful in assessing whether or not a catchment has reached new chloride equilibrium. The six conceptual catchment types are tested with eleven selected catchments in the Mount Lofty Ranges (MLR), a coastal hilly area in South Australia having experienced widespread historical forest clearance. The results show that six of the eleven catchments match a type VI chloride balance condition (chloride non-equilibrium with a gaining stream), with the ratios of stream chloride output $(\mathrm{O})$ over atmospheric chloride input (I), or catchment chloride $\mathrm{O} / \mathrm{I}$ ratios, ranging from 2 to 4 . Two catchments match a type $\mathrm{V}$ chloride balance condition (chloride non-equilibrium with a losing stream), with catchment chloride $\mathrm{O} / \mathrm{I}$ ratios about 0.5. For these type $\mathrm{V}$ and type VI catchments, the CMB method is not applicable. The results also suggest that neither a chloride $\mathrm{O} / \mathrm{I}$ ratio less than one nor a low sea-
\end{abstract}

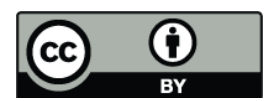

Correspondence to: $\mathrm{H}$. Guan (huade.guan@flinders.edu.au) sonal fluctuation of streamflow chloride concentration (a factor below 4) guarantees a chloride equilibrium condition in the study area. A large chloride O/I value (above one) and a large fluctuation of streamflow chloride concentration (a factor of 10 and above) generally indicates either a chloride disequilibrium, or cross-catchment water transfer, or both, for which the CMB method is not applicable. Based on regression between chloride $\mathrm{O} / \mathrm{I}$ values and annual precipitation for type VI catchments, a catchment with annual precipitation of $900 \mathrm{~mm}$ in MLR has most likely reached new chloride equilibrium, and the CMB method can be applied if no cross-catchment water transfer occurs. CMB is applied to one catchment at chloride equilibrium, suggesting a net groundwater recharge of $27 \mathrm{~mm} / \mathrm{yr}$, about $3 \%$ of annual precipitation.

\section{Introduction}

Among the various approaches for estimating groundwater recharge, the chloride mass balance (CMB) method is one of the most frequently used, especially for arid and semiarid regions (Petheram et al., 2002; Scanlon et al., 2002; Wilson and Guan, 2004). The basic idea of the CMB method is that the atmospheric input of chloride in precipitation as well as dry deposition is concentrated in the residual soil water via evapotranspiration (ET) processes. By measuring chloride concentration in soil water, or the resulting groundwater, we can estimate the (potential, if soil chloride is used) recharge rate.

The CMB method can be applied to the saturated zone (Eriksson and Khunakasem, 1969; Dettinger, 1989; Wood and Sanford, 1995), or unsaturated zone (Walker et al., 1991; Cook et al., 1992; Phillips, 1994; Scanlon and Goldsmith,

Published by Copernicus Publications on behalf of the European Geosciences Union. 
1997; Edmunds et al., 2002). In terms of spatial extent, the method can be applied in one dimension (1D), or be integrated over a catchment (Dettinger, 1989). When the CMB is based on chloride profiles in the unsaturated zone, onedimensional piston flow is assumed. Wood (1999) identified three uncertainties when the 1D CMB method is applied. It is difficult to quantitatively determine the chloride input to the profile due to run-on and runoff processes; the method does not measure macropore-flow recharge if soil matrix chloride concentration is used; and it is sometimes difficult to evaluate whether or not the profile is in a chloride-flux steady state. When these problems are resolved, the 1D CMB method is a good tool for investigating the spatial variability of groundwater recharge (Cook et al., 1989).

In mountainous terrain, a major problem in calculating the 1-D chloride mass balance is the difficulty of determining chloride inputs, because lateral runoff and interflow alter chloride input from atmospheric deposition. Although mathematically, this run-on and runoff effect can be accounted for in the CMB equation (Wood, 1999), it relies on accurate estimation of runoff volume and chloride concentration in runoff water. Chloride concentration in runoff water is often several times larger than that in rain water. In an arid area, a tenfold difference was reported by Flint et al. (2002). Not accounting for this runoff would introduce a large uncertainty in the CMB calculation results. Also, owing to high spatial variability in precipitation, ET and soil characteristics, it is very difficult to estimate groundwater recharge over the catchment based on a few 1D chloride mass balance calculations. These problems can be resolved by applying the CMB method over the whole catchment, since chloride in runoff water is integrated and can be measured at the catchment stream outlet. Application of the CMB method over a catchment is commonly used to estimate mountain front (or block) recharge (Wilson and Guan, 2004; Wahi et al., 2008; Ma et al., 2009). To distinguish this application of CMB from the 1D-based $\mathrm{CMB}$, it is referred to as the catchment CMB method. The catchment $\mathrm{CMB}$ is the focus of this paper.

Due to the high temporal variability of both atmospheric water and chloride inputs, and retarded response of recharge and especially chloride in the resulting groundwater, the catchment $\mathrm{CMB}$ method is used to estimate the average recharge rate over several years or more. Short-term recharge fluctuations due to seasonality and inter-annual climate variability are not discussed in this paper. One of the major assumptions of the catchment CMB method is that the groundwater recharge rate of the catchment is in equilibrium with near-surface and atmospheric conditions in terms of both water and chloride fluxes over the whole catchment. Additional assumptions can be found in Wood (1999). As previously discussed, an equilibrium condition in the $1 \mathrm{D}$ profile is also required for $\mathrm{CMB}$ applications. Only when the soil chloride profile is in equilibrium with historical surface and climate conditions, and has not been disturbed by recent changes, can the 1D CMB be applied to each part of the chloride pro- file (Cook et al., 1992, Phillips 1994). After a surface condition change (e.g., forest clearance), the time to reach a new chloride equilibrium varies from place to place in the catchment. A new catchment chloride equilibrium condition is reached only when a new equilibrium is attained in all parts of the catchment, but it is possible that the 1-D CMB can be applied to some areas of the catchment before the wholecatchment CMB method can be performed. However, because of the above-mentioned difficulties, in particular those resulting from lateral water movements, few studies have attempted to apply the 1D CMB to mountain catchments.

When the catchment CMB method is applied, it is important and critical to check the equilibrium assumption, especially in areas of significant land use change, such as the coastal and some inland areas of Australia. As in many other countries, coastal areas of Australia house a large portion of the population and economic activities. Quantification of water resources in these areas, including groundwater recharge, is critical for various aspects of economic and societal development. Mountainous and hilly terrains in Australian coastal areas enhance precipitation, providing a significant amount of water resources to the area. With increasing awareness of the impact of climate change on water supply, estimates of groundwater resources have become more urgent. Because of its simplicity, the CMB method is a common method of estimating recharge (Petheram et al., 2002), but two problems need to be resolved. First, widespread native vegetation clearance for agriculture since European settlement about 150 years ago has changed the land surface boundary condition, posing the question as to whether the current system has reached a new chloride equilibrium condition. Another challenge is that the spatial variability of atmospheric chloride input is large in coastal areas (Kayaalp, 2001), so reliable estimates of atmospheric chloride inputs are difficult. The latter issue was recently addressed for the Mount Lofty Ranges (MLR) in South Australia (Guan et al., 2010). The focus of this present paper is to examine the first issue, i.e., whether MLR catchments have reached a new chloride equilibrium.

Impacts of vegetation clearance on catchment water chemistry have been observed for decades (Peck and Hurle, 1973; Likens et al., 1978; Williamson et al., 1987). These and some other studies were performed mainly to address dryland salinity issues (Jolly et al., 2000; Kayaalp and Bye, 2003; Poulsen et al., 2006). Few were directly linked to CMB applications. Modelling efforts have been made to estimate the time required to reach post-clearance equilibrium (Sivapalan et al., 1996; Smitt et al., 2003; Dawes et al., 2004; Gilfedder et al., 2009), which provide a good tool to understand catchment response to forest clearance. These models require input data pertaining to surface conditions and subsurface hydrogeological properties. Surface conditions, such as topography, vegetation coverage, precipitation, saltfall, streamflow and its salinity, are often available, while subsurface hydrogeological properties are difficult to estimate. In 
this paper, we examine catchment $\mathrm{CMB}$ applicability based on surface condition data. The method described indicates whether or not a catchment has reached a new post-clearance chloride equilibrium, a requirement for valid application of the catchment CMB method. It does not provide the trajectories of catchment responses to forest clearance as modelling approaches do.

Catchment stream chloride (or salt) load changes after clearance, and will eventually reach a new equilibrium status. Examination of the catchment chloride budget may provide valuable information for revealing the current catchment chloride equilibrium status (i.e., how far a system is from the new equilibrium). In addition to forest clearance, the catchment chloride budget is also influenced by climate, catchment hydrology (e.g., gaining vs. losing streams) and crosscatchment water transfers. To make the catchment chloride budget useful for estimating catchment chloride equilibrium status, these factors should be considered, but a conceptual framework which includes all processes that influence the chloride budget is lacking in the literature. Climate is considered an important factor influencing post-clearance catchment chloride response (Jolly et al., 2001), but attempts to link climate and catchment chloride balance to estimate catchment chloride equilibrium status have not been reported. The primary objectives of this study are (1) to conceptualize catchment chloride equilibrium conditions and their quantitative indicators, (2) to demonstrate how these conceptual models, combined with climate information, are useful in assessing whether a catchment has reached a new chloride equilibrium for the CMB application, (3) to identify catchments in a coastal hilly region of South Australia that are valid for CMB application, and (4) estimate catchment groundwater recharge for these catchments.

\section{Catchment chloride balance and the conceptualisation}

The hydrological processes that influence chloride mass balance in a typical mountainous catchment are illustrated in Fig. 1. Atmospheric chloride is brought to the catchment by wet deposition with precipitation and dry deposition (Guan et al., 2010), and then transported by infiltrating and runoff water. Evapotranspiration concentrates chloride in the residual water, but does not move it. Chloride is added to the groundwater by direct water-table recharge (Meinzer, 1923). Phreatophyte transpiration and capillary rise due to a shallow groundwater table (Dingman, 1994) concentrates chloride in groundwater, but these effects cannot be separated from other ET processes using chloride mass balance. Their effects are lumped together, and net water-table recharge refers to direct water-table recharge minus capillary rise and phreatophyte transpiration. As vertical input of chloride is difficult to quantify due to lateral movement of chloride with runoff, it is difficult to estimate net water-table recharge using the
CMB approach. In a catchment with a losing stream, runoff chloride can be measured in the stream at the catchment outlet. For most situations, base flow also contributes water and chloride to the stream. Assuming that chloride concentration in the base flow is equal to that of net water-table recharge, the $\mathrm{CMB}$ can be written as

$P \cdot C_{p}=R_{n} \cdot C_{R}+q \cdot C_{q}$

where $C_{p}$ is chloride concentration in bulk precipitation, $P$ is precipitation in the catchment, $C_{R}$ is chloride concentration in net water-table recharge (generally, water near the water table is sampled to avoid chloride contamination from historical recharge or from regional recharge), and $R_{n}$ is the net water-table recharge minus base flow (referred to as net catchment recharge in this paper), $q$ is the streamflow measured at the catchment outlet, and $C_{q}$ is chloride concentration of the stream water. This equation also applies to catchments where base flow is absent, where net catchment recharge is equal to net water-table recharge. In mountain terrain, net catchment recharge can be considered as the catchment contribution to the total mountain block recharge. For Eq. (1) to be applicable, groundwater recharge and chloride flux should be in equilibrium with current surface and climate conditions. Under this situation, for a catchment without chloride sources and sinks, the ratio of the catchment chloride mass loss (output) through streamflow $\left(\mathrm{O}=q \cdot C_{q}\right)$ to total chloride mass input from atmospheric deposition ( $\mathrm{I}=P \cdot C_{p}$ ), or the chloride $\mathrm{O} / \mathrm{I}$ ratio, should be no more than one. An equivalent $\mathrm{O} / \mathrm{I}$ ratio for water is also used in this paper. The water $\mathrm{O} / \mathrm{I}$ ratio is defined as the ratio of annual streamflow exporting water out of the catchment to annual precipitation bringing water into the catchment.

The chloride (or salt) O/I ratio has been shown, used, or considered to be useful in indicating the impact of forest clearance on catchment chloride equilibrium status in many case studies (Peck and Hurle, 1973; Williamson et al., 1987; Cook et al., 1989; Williamson and van de Wel, 1991; Jolly et al., 2001; Peck and Hatton, 2003). Salt (chloride) O/I ratios have been observed to increase after forest clearance. Peck and Hurle (1973) examined 15 catchments of various sizes within $150 \mathrm{~km}$ from the coast in southwest Western Australia, of which eight were forested and seven were farmland, partially cleared within the past 150 years. Their results show that in the forested catchments, the salt $\mathrm{O} / \mathrm{I}$ ratio is about 1 to 1.6, while for the farmland the ratio ranges from 3 to 21 . In the MLR of South Australia, where widespread forest clearance occurred after European settlement, Williamson and van der Wel (1991) examined the salt O/I ratio for 21 selected catchments, and found that 19 catchments had a salt $\mathrm{O} / \mathrm{I}$ ratio between 3 to 9 . These observations suggest that vegetation clearance perturbs catchment water and salt (chloride) equilibria established under pre-clearance conditions, and suggest that in some situations the catchment chloride $\mathrm{O} / \mathrm{I}$ ratio could be used as a quantitative indicator inferring chloride equilibrium status. 


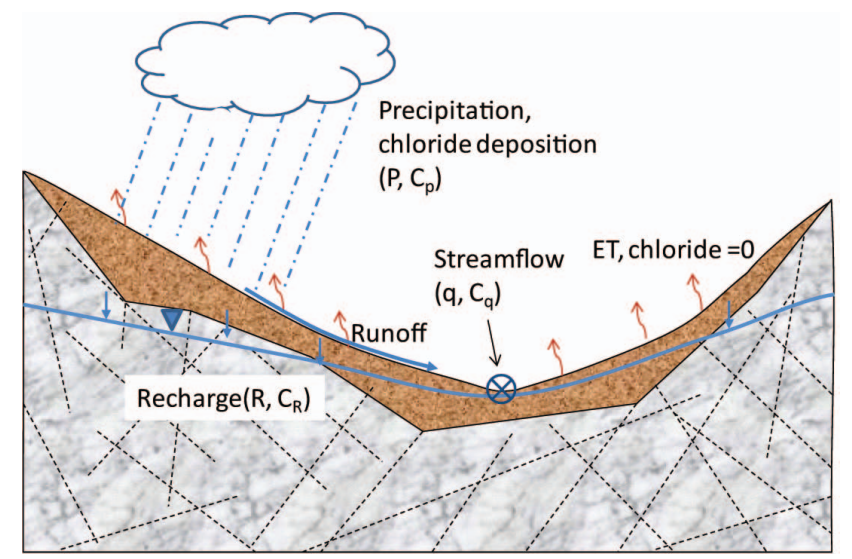

Fig. 1. A conceptual mountainous catchment showing hydrological processes involved in catchment chloride mass balance (modified from Dettinger 1989), where $P$ is precipitation, $C_{p}$ is bulk chloride concentration, ET is evapotranspiration, $R$ is net water-table recharge (net water vertically added to the groundwater table from vadose zone), $C_{R}$ is the mean recharge groundwater chloride concentration, $q$ is streamflow at the catchment outlet point, and $C_{q}$ is the streamflow mean chloride concentration. The upper zone of the cross section represents shallow colluvial type deposits, and while the lower zone represents fracture rock.

The feasibility of using chloride O/I ratios for determining catchment chloride equilibrium status is demonstrated in the six conceptual catchments (Fig. 2). Two catchment types (I and II) represent chloride equilibrium conditions for which the CMB can be applied for estimating groundwater recharge, two (type III and IV) are in chloride equilibrium but contaminated by cross-catchment chloride transfer, and two (types $\mathrm{V}$ and VI) are non-equilibrium conditions, for which CMB is not applicable. These six conceptual catchments do not exhaust all possibilities. For example, cross-catchment water transfer can occur in chloride non-equilibrium catchments, and to catchments with a losing stream, not necessarily limited to type III and IV. Following similar conceptualisation, one may add more classes. We will discuss chloride balance and estimate chloride O/I ratios for each of the six conceptual catchment types. It should be noted that many of the chloride mass balance equations discussed here are used to illustrate and understand various components of catchment chloride balance, but are not suitable as a CMB method for calculating groundwater recharge because some components cannot be measured.

For a type I catchment (Fig. 2, panel I), with a losing stream (average condition of the whole catchment, not necessarily the condition at the catchment outlet point), the catchment chloride mass balance is

$$
P \cdot C_{p}=R \cdot C_{R}+q_{e} \cdot C_{e}
$$

where $C_{R}$ is chloride concentration in net water-table recharge $R, q_{e}$ is the event flow (quantitatively equal to
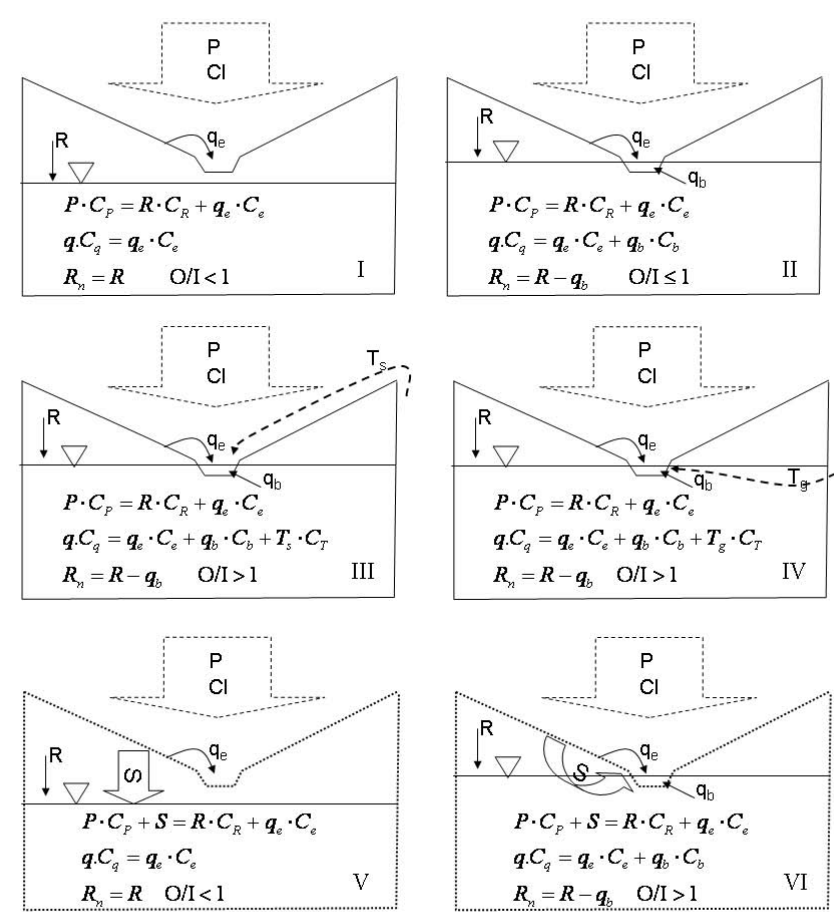

Fig. 2. Conceptualisation of catchment chloride balance under various conditions: (I) Chloride steady state with a losing stream, (II) Chloride steady state with a gaining stream, (III) Chloride steady state, with cross-catchment surface water transfer, (IV) Chloride steady state, with cross-catchment subsurface water transfer, (V) Chloride non-steady state, in which historical soil chloride is primarily leached to groundwater, and (VI) Chloride non-steady state, in which historical soil chloride is leached to both surface water and groundwater. The losing and gaining streams are average situations of the whole catchment, not necessarily the condition at the catchment outlet point. $P$ is precipitation, $R$ is direct groundwater recharge, $q_{e}$ is the event streamflow, $q_{b}$ is base flow from direct-recharge groundwater, $T$ is the cross-catchment water transfer, $R_{n}$ is net groundwater recharge; average values are used across the whole catchment in units of $\mathrm{mm} . \mathrm{Cl}$ is for chloride deposition in $\mathrm{mg} \mathrm{m}^{-2} \mathrm{yr}^{-1}, C$ is the chloride concentration $\left(\mathrm{mgl}^{-1}\right)$ of various water flux indicated by the subscript, in which $C_{p}(=C l / P)$ is the bulk precipitation chloride concentration. $S$ is the re-mobile historical soil chloride leached into the stream and groundwater $\left(\mathrm{mg} \mathrm{m}^{-2} \mathrm{yr}^{-1}\right.$ ) over the whole catchment. $O$ and $I$ denote chloride being exported out of the catchment via streamflow measured at the outlet point, and chloride input from atmospheric deposition to the catchment, respectively.

streamflow in this case), and $C_{e}$ is chloride concentration of the event flow. Because no base flow occurs, chloride in recharged groundwater from the catchment does not return to the surface. Net catchment recharge is equal to net watertable recharge, and can be estimated by (1). As only part of atmospheric chloride deposition is exported out of catchment by event flow, the chloride $\mathrm{O} / \mathrm{I}$ ratio is less than one (Fig. 2, panel I). 
For a type II catchment (Fig. 2, panel II), part or all of the groundwater recharge and its dissolved chloride returns to the surface, and is exported from the catchment. Chloride in stream water is derived from that in event flow and base flow,

$q \cdot C_{q}=q_{e} \cdot C_{e}+q_{b} \cdot C_{b}$

where $q_{b}$ is the base flow, and $C_{b}$ is chloride concentration of the base flow, other symbols are defined previously. Net catchment recharge is smaller than net water-table recharge, and can be estimated by Eq. (1) with an assumption that chloride concentration in base flow is the same as that in the net water-table recharge. In a type II catchment, the chloride O/I ratio can be smaller than or equal to one.

Type III and type IV catchments (Fig. 2, panels III and IV) are those influenced by cross-catchment water transfer, with type III having surface water transfer, and type IV having subsurface water transfer. Chloride in the stream water is the sum of that from event flow, base flow, and cross-catchment transfer water,

$q \cdot C_{q}=q_{e} \cdot C_{e}+q_{b} \cdot C_{b}+T \cdot C_{T}$

where $T$ is cross-catchment transfer water flow, and $C_{T}$ is chloride concentration in the cross-catchment transfer water. The chloride $\mathrm{O} / \mathrm{I}$ ratio most likely exceeds one, depending on the relative amount of transferred water. The water $\mathrm{O} / \mathrm{I}$ ratio of a type III or IV catchment is significantly larger than that of a type I or II catchment. Generally, the CMB method is not applicable to a type III or IV catchment. However, if the surface water transfer is quantified, net catchment groundwater recharge can be estimated for a type III catchment by Eq. (5), with assumption that $C_{b}$ is equal to $C_{R}$,

$$
P \cdot C_{P}+T \cdot C_{T}=R_{n} \cdot C_{R}+q \cdot C_{q}
$$

with symbols defined previously. In a type IV catchment, cross-catchment water and chloride inputs occur in the subsurface. If these fluxes are located at depth and do not affect shallow groundwater and stream water, they can be neglected. The catchment can be regarded as a type II catchment. Otherwise, the CMB method is not applicable because $T$ is not known.

Type V and VI catchments (Fig. 2, panel V and VI) represent post-clearance situations in which historical chloride accumulated in the vadose zone under pre-clearance conditions is now released into groundwater and surface water. Catchment chloride balance is described by

$$
P \cdot C_{P}+S=R \cdot C_{R}+q_{e} \cdot C_{e}
$$

where $S$ is remobilised historical soil chloride. For a type $\mathrm{V}$ catchment, base flow does not occur, the chloride O/I ratio is likely smaller than one because of low horizontal subsurface flow bringing soil chloride into the stream. In a type VI catchment, base flow and horizontal subsurface flow deliver historical chloride into the stream, and the chloride $\mathrm{O} / \mathrm{I}$ ratio is larger than one. As catchment chloride is not in equilibrium with current surface and atmospheric conditions in a type V or VI catchment, the CMB method is not applicable to either of them.

We examined these conceptual catchment types in relation to some published observations. Williamson et al. (1987) studied five catchments in southwest Western Australia over ten years (Table 1). Assuming that the forested catchments were in chloride equilibrium, and the cleared catchments were in disequilibrium after recent clearance, a type I condition can be ascribed to the Ernies catchment, a type II or IV condition to the Salmon catchment, a type VI condition, probably with cross-catchment transfer (inferred from the large water $\mathrm{O} / \mathrm{I}$ ratio) to the Wights catchment, and a type $\mathrm{V}$ condition to the Dons and Lemon catchments.

How are the conceptual catchment types and chloride O/I ratios used to determine CMB applicability? Generally, the CMB method is not valid for a catchment with a chloride $\mathrm{O} / \mathrm{I}$ ratio larger than one. If cross-basin chloride transfer is excluded, a chloride $\mathrm{O} / \mathrm{I}$ ratio much greater than one is a good indicator of chloride non-equilibrium with current surface and atmospheric conditions. Since chloride O/I ratios can be below one for both equilibrium and non-equilibrium conditions, it is difficult to determine whether the CMB method applies to catchments having chloride $\mathrm{O} / \mathrm{I}$ ratios less than one. In this situation, additional information, such as climate, topography, catchment size, soil types and thickness, and aquifer properties may be helpful (Jolly et al., 2001; Dawes et al., 2004). Generally, it takes a longer time for catchments to reach a new chloride equilibrium in drier climates (Jolly et al., 2001). Although factors such as vadose zone thickness may influence the time to equilibrium, the climate condition gives a good first-order approximation. This climate-dependent catchment chloride response can be used to determine CMB applicability. For the three cleared catchments in Table 1, Wights was not in equilibrium, indicated by a chloride O/I ratio of 9.8 and the other two catchments (Dons and Lemon), with vegetation cleared at the same time as Wights, are not yet in steady state because they are drier than Wights.

\section{Methodology}

\subsection{Study area and data}

Catchment chloride equilibrium conditions in eleven catchments in the MLR of South Australia were examined (Table 2). The MLR are located east of Adelaide, South Australia (Fig. 3), covering an area of about $9000 \mathrm{~km}^{2}$ with topographic relief of $700 \mathrm{~m}$. Bedrock is primarily late Precambrian metamorphic sedimentary rock composed of shale and sandstone, and some limestone (Preiss, 1987). Climate is Mediterranean, with annual precipitation ranging from below $300 \mathrm{~mm}$ to above $1000 \mathrm{~mm}$ (Guan et al., 2009). Prior 
Table 1. Water and chloride ratios of five experimental catchments in (Williamson et al., 1987) and their corresponding chloride equilibrium types (The forest clearance occurred at the end of 1976. All quantities were measured during the data period).

\begin{tabular}{llllllll}
\hline & Catchment & Area km & Data period & Precipitation $\mathrm{mm} \mathrm{yr}^{-1}$ & Water O/I & Cl O/I & Type \\
\hline \multirow{2}{*}{ Forested } & Salmon & 0.82 & $1974-1983$ & 1123 & 0.11 & 1.37 & II or IV \\
& Ernies & 2.70 & $1974-1983$ & 738 & 0.02 & 0.09 & I \\
& Wights & 0.94 & $1977-1983$ & 1027 & 0.31 & 9.79 & VI \\
\multirow{2}{*}{ Cleared } & Dons & 3.50 & $1977-1983$ & 721 & 0.02 & 0.14 & V \\
& Lemon & 3.44 & $1977-1983$ & 737 & 0.03 & 0.22 & V \\
\hline
\end{tabular}

Table 2. Eleven selected catchments in the Mount Lofty Ranges and related site information.

\begin{tabular}{|c|c|c|c|c|c|c|c|}
\hline Catchment & Gauge ID & Easting $\mathrm{m}$ & Northing m & Data-period $^{1}$ & Area $\mathrm{km}^{2}$ & Elevation $^{2} \mathrm{~m}$ & Slope degree \\
\hline 1. Bremer at $\mathrm{U} / \mathrm{S}$ & 4260688 & 320374 & 6110330 & $1998-2007$ & 195 & $260(67-534)$ & 6 \\
\hline 2. Western Flat Creek & 4261018 & 303709 & 6116027 & 2005-2006 & 33 & $382(317-472)$ & 5 \\
\hline 3. Bremer at Bletchley & 4261070 & 317686 & 6097406 & $2005-2008$ & 604 & $252(28-534)$ & 6 \\
\hline 4. Finniss River & 4261075 & 297642 & 6089905 & $2005-2008$ & 278 & $307(102-481)$ & 7 \\
\hline 5. Currency Creek & 4261099 & 296277 & 6074320 & $2007-2008$ & 76 & $215(15-400)$ & 6 \\
\hline 6. Giles Creek & 4261103 & 300432 & 6085034 & $2007-2008$ & 30 & $154(30-372)$ & 5 \\
\hline 7. Onkaparinga at Houlgrave & 5030504 & 292589 & 6115458 & $2008 / 2009$ & 334 & $412(223-704)$ & 7 \\
\hline 8. Onkaparinga at Hahndorf & 5030537 & 298622 & 6122518 & $2003-2007$ & 229 & $420(295-615)$ & 6 \\
\hline 9. Pedler Creek & 5030543 & 274330 & 6101476 & $2001-2005$ & 85 & $164(40-405)$ & 6 \\
\hline 10. Torrens River at Mt. Pleasant & 5040512 & 319631 & 6148870 & $2006 / 2008$ & 26 & $465(413-543)$ & 3 \\
\hline 11. North Para River at Mt. McKenzie & 5050533 & 323834 & 6172797 & $1997-2007$ & 44 & $440(364-584)$ & 4 \\
\hline
\end{tabular}

1998-2007 indicates whole-year record from 1998 to 2007 (inclusive), and 2006/2008 indicates part-year record for the two endyears. This is elevation calculated from $25 \mathrm{~m}$-DEM, with the first number being average elevation above sea level, and the two numbers in the brackets being the elevation range of the catchment.

to European settlement the whole area was covered by native eucalyptus forest and woodland, and is assumed to have been in chloride equilibrium. Starting about 150 years ago, vegetation was cleared, primarily for agricultural and residential use, and this continued until 1983 when government controls were instituted (Glanznig, 1995). Native vegetation coverage in the MLR is currently about $10 \%$ of that prior to European settlement. Historical vegetation clearance has dramatically altered surface conditions and disturbed the preclearance catchment chloride equilibrium.

Have the catchments reached new chloride equilibrium? This question needs to be answered before the CMB method is used to estimate groundwater recharge. Besides land use change, cross-catchment water transfer and reservoirs have modified local hydrology, including both water and chloride balance. There are 15 reservoirs in the area, and three pipe lines convey water from the Murray River (Fig. 3) to the MLR, all of which add complexity to CMB applications. To avoid this complexity, eleven catchments without upstream reservoirs were selected, one of which (catchment 7, Table 2) had a pipeline outlet which enabled examination of the effect of cross-catchment water transfer on chloride balance. Daily streamflow and electrical conductivity (EC) data for each catchment was downloaded (http: //e-nrims.dwlbc.sa.gov.au/swa/) and summarized (Table 2). Maps (1 km resolution) of annual chloride deposition (Guan et al., 2010) and annual precipitation (Guan et al. 2009) were used to define spatial variability of water and chloride inputs. After the CMB applicability was tested, groundwater chloride data (Radke et al., 2000; Green et al., 2007) were used to estimate groundwater recharge. Locations of these samples are shown in Fig. 3. The majority of these data are from Radke et al. (2000), and some are from Green et al. (2007).

\subsection{Chloride budget calculation}

Chloride and water inputs were calculated from chloride deposition and precipitation maps for each catchment, clipped to the catchment boundaries (Fig. 3) using ARCGIS Toolbox. Average annual streamflow and chloride load were calculated from measured daily streamflow and EC data for years during which both were available. In case some measurements (less than 10\%) were missing in a month, average values for the month were used for the missing days. Climate conditions during the data period were similar to the post-clearance long-term average (not shown). In mountainous catchments the average time of contact of stream water with bedrock is short, so the bedrock effect should be very 


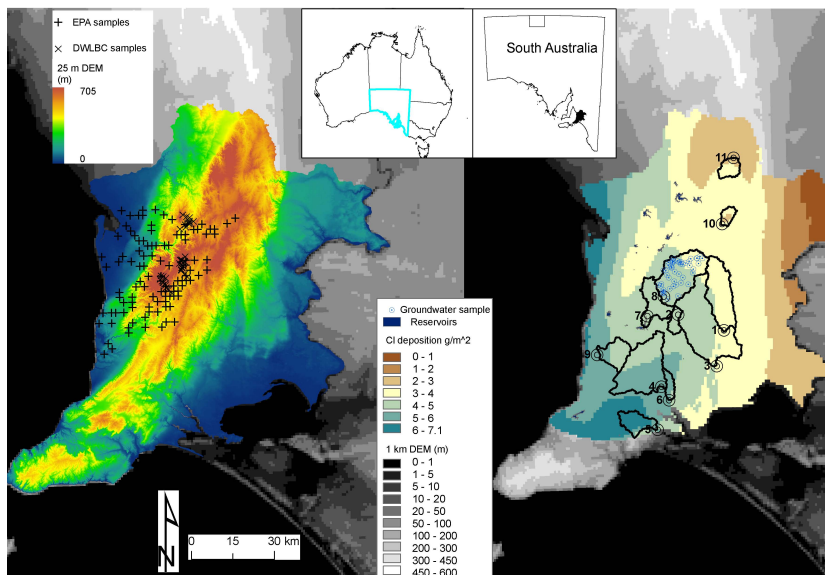

Fig. 3. The study area, left-hand side: digital elevation map showing the Mount Lofty Ranges (MLR), with stream water samples used to derive the relationship between chloride concentration and EC measurements (data from DWLBC and EPA), and right-hand side: eleven catchments of the MLR (the numbers correspond to those in Table 2), overlying the annual chloride deposition map with groundwater sample locations of chloride concentration for CMB application. Note that catchment 7 includes catchment 8 , and catchment 3 includes catchment 1 . The river to the east of MLR, flowing to the south, is the Murray River, which provides about $50 \%$ of water for the Adelaide metropolitan area via three main pipe lines through MLR (not shown). The inserts of Australia and South Australia maps are included to show regional location of the study area.

small. Since chloride concentrations in streamflow were not measured, 450 surface water analyses from the Department of Water, Land and Biodiversity Conservation (DWLBC), and the Environmental Protection Authority (EPA), of South Australia (Fig. 3) were used to develop an exponential relationship between chloride concentration and EC (Fig. 4). A similar function was obtained and applied to the Murray River and its tributaries (White et al., 2009), an area much larger than this study area.

\subsection{Relating chloride equilibrium status with climate and surface conditions}

How is a catchment chloride budget used to determine whether or not the CMB method applies? As both chloride equilibrium (types I and II) and disequilibrium (type V) catchments can have a chloride $\mathrm{O} / \mathrm{I}$ ratio below or equal to one, it is difficult to differentiate type $\mathrm{V}$ catchments from type I and II catchments using chloride O/I ratios only. Type VI catchments have chloride $\mathrm{O} / \mathrm{I}$ ratios larger than one, which are easier to distinguish from type I and II catchments. They are distinguished from type III and IV catchments by the presence of known cross-catchment water transfer, or by their water $\mathrm{O} / \mathrm{I}$ ratios, which are usually much higher than type V or VI catchments. Assuming that, under similar climate conditions, type $\mathrm{V}$ catchments have similar chloride

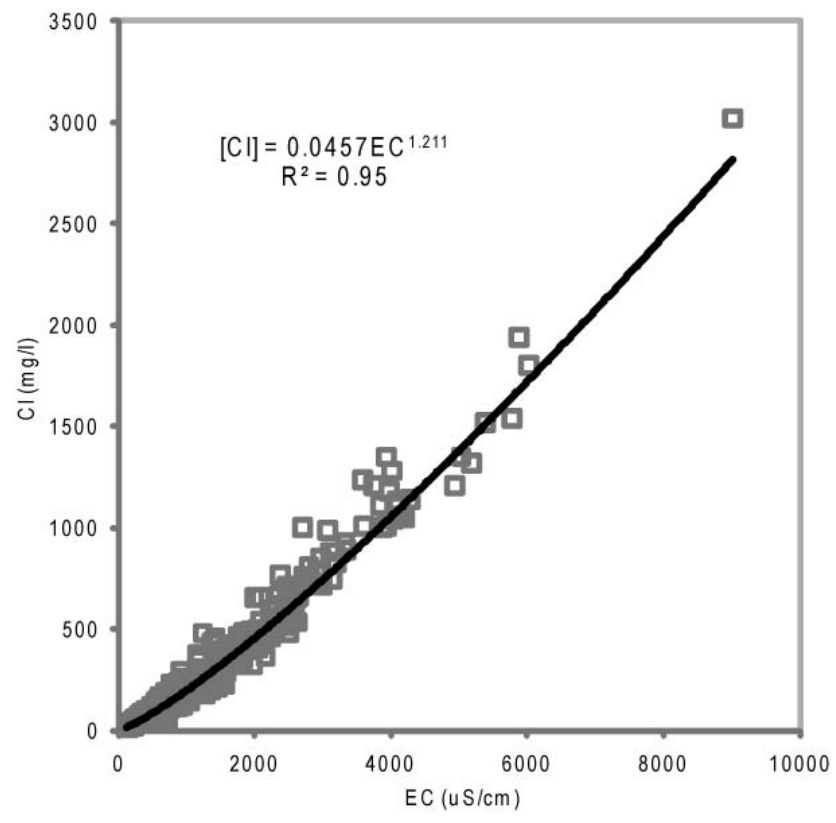

Fig. 4. Measured chloride concentration of stream water vs. measured electrical conductivity values, based on 306 samples by EPA mainly collected in May and October, and 145 samples by DWLBC collected in November, December, March, and July.

equilibrium status as type VI catchments that experienced similar historical forest clearance, the relationship between chloride equilibrium status and some climatic/hydrological variables developed for type VI catchments will also apply to type V catchments. Surface characteristics such as elevation, slope and catchment size, were examined in addition to climate. Aquifer properties, which control the timing of regional groundwater to reach a new equilibrium, were not considered for the following four reasons: (1) In applying the CMB to recharge estimation, only equilibrium chloride concentration in the vadose zone and shallow groundwater that connects to the stream is important. Climate, topography, and vadose zone characteristics are more important than aquifer properties in controlling the timing of catchment chloride response to vegetation clearance. (2) Differences between catchments reflect differences in the chloride $\mathrm{O} / \mathrm{I}$ ratio after vegetation clearance. Variability of climate across the MLR is high, with precipitation ranging below $300 \mathrm{~mm} \mathrm{yr}^{-1}$ to above $1000 \mathrm{~mm} \mathrm{yr}^{-1}$, therefore precipitation probably determines the variability of catchment chloride equilibrium status. (3) Practically, the factors used to estimate catchment chloride equilibrium status should be economically and technically feasible to obtain, which excludes aquifer properties in mountainous areas. (4) If aquifer properties were important, their effects would overshadow other factors (such as precipitation), reducing the correlation between chloride $\mathrm{O} / \mathrm{I}$ and precipitation, but it is shown later that this is not the case in our study area. Hydrogeological 


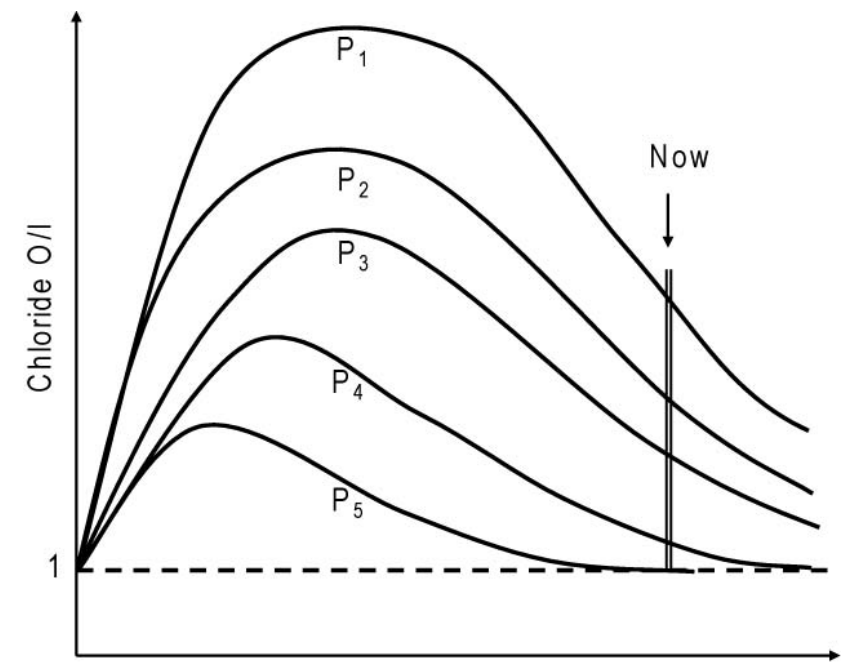

Time since clearance

Fig. 5. Conceptualized evolution paths of type VI catchments starting from the forest clearance to type II catchments as a function of climate conditions, where $P_{i}$ is mean annual precipitation; it increases from $P_{1}$ to $P_{5}$ (extended from Fig. 2 in Jolly et al., 2001).

properties of the vadose zone, such as soil types and thickness, are associated with surface conditions such as climate and topography (Birkeland, 1999), and are thus related to the surface factors examined.

To demonstrate how surface conditions are used to estimate catchment chloride equilibrium status, imagine what happens to type II catchments after vegetation clearance, when they temporalily become type VI catchments. Because of different local climate conditions, these type VI catchments will undergo different evolution paths toward their new type II equilibrium status (Fig. 5). Catchment chloride $\mathrm{O} / \mathrm{I}$ ratio is a good indicator of the chloride equilibrium status of type II/VI catchments. At a certain time point, chloride $\mathrm{O} / \mathrm{I}$ ratios can be examined for all type VI catchments of various climate conditions (Fig. 5). Although it is difficult to predict how long each of these catchments will take to reach new chloride equilibrium, it is possible to identify the conditions under which a catchment has currently reached chloride equilibrium. This is the information required before applying the CMB method to estimate groundwater recharge. Correlation analysis between chloride $\mathrm{O} / \mathrm{I}$ ratio and climate variables (e.g. precipitation), as well as other selected variables (water O/I, streamflow, catchment area, elevation, and slope), were performed to find likely relationships between them. Regression between chloride O/I and significant correlated variable(s) was performed to obtain a prediction relationship. This relationship can then be used to examine chloride equilibrium status of a catchment which experienced similar forest clearance history.

\section{Results and discussion}

\subsection{Catchment chloride budget}

Water and chloride $\mathrm{O} / \mathrm{I}$ ratios for the eleven catchments studied are summarized in Table 3. Water $\mathrm{O} / \mathrm{I}$ ratios are below 0.1 for 9 of the 11 catchments, with two exceptions. The ratio is 0.32 for the Onkaparinga catchment (catchment 7 in Table 3) above the stream gauge at Houlgrave. This high value is caused by the input of Murray-River water at an upstream location. The chloride $\mathrm{O} / \mathrm{I}$ ratios is 7.1, indicating, based on our definitions in Fig. 2, that this is a type III catchment; further evidence is discussed later. Another exception is the North Para River catchment (11 in Table 3) with a stream gauge at Mt. McKenzie. The water O/I ratio for this catchment is 0.23 , with an abnormally high chloride $\mathrm{O} / \mathrm{I}$ ratio of 31.4. Monthly hydrograph and stream chloride concentration are shown in Fig. 6a. Neither cross-catchment surface water transfers nor industrial water effluents are present. The monthly hydrograph shows peak flow occurring in rainy seasons, so it is likely that cross-catchment groundwater transfer occurs. The abnormally high chloride $\mathrm{O} / \mathrm{I}$ ratio indicates a chloride disequilibrium condition, a conclusion supported by large fluctuations of stream water chloride concentrations which range from below $200 \mathrm{mg}^{-1}$ during the event flow to about $4000 \mathrm{mgl}^{-1}$ at the beginning of rainy seasons. This catchment is possibly a combination of types VI and IV. Except for these two, six of the remaining nine catchments $(1$, 2, 4, 5, 6, and 10 in Table 3) have chloride $\mathrm{O} / \mathrm{I}$ ratios ranging from 2 to 4 . They are most likely type VI catchments. An example of a type VI hydrograph and stream chloride concentrations is shown in Fig. $6 \mathrm{~b}$ for the Bremer catchment (1 in Table 3). It has a large stream water chloride concentration range (from 300 to $3700 \mathrm{mg} \mathrm{l}^{-1}$ ), similar to the North Para River catchment, which is good evidence of a type VI catchment.

The remaining three catchments $(3,8$ and 9 in Table 3$)$ have chloride $\mathrm{O} / \mathrm{I}$ ratios around 0.5 . They are either type I, II, or type V catchments. Catchment (3) has a type VI sub-catchment (catchment 1 in Fig. 3); thus it should be in chloride disequilibrium and thus a type $\mathrm{V}$ catchment. Because accumulated antecedent soil chloride is not leached into the stream, stream chloride concentrations in type $\mathrm{V}$ catchments do not fluctuate as much as in type VI catchments. This is evident in the time series of monthly chloride concentration for catchment 3 in Fig. $6 c$, showing that stream water chloride concentrations range only from $300 \mathrm{mg} \mathrm{l}^{-1}$ to about $800 \mathrm{mg}^{-1}$. For catchment 8 , the hydrograph (Fig. 6d) shows that base flow persists throughout the year. It cannot be a type VI catchment based on the chloride O/I ratio and is most likely a type II catchment. This is supported by a low stream chloride concentration range (slightly above $100 \mathrm{mg} \mathrm{l}^{-1}$ to about $400 \mathrm{mg} \mathrm{l}^{-1}$ ). As base flow in dry seasons is so small, resulting in negligible chloride load from base flow in contrast to event flow chloride load (not shown), 
Table 3. Atmospheric input and streamflow output of water and chloride of the eleven catchments and their possible corresponding chloride equilibrium status (The precipitation and chloride deposition data were calculated from the long-term average distribution maps, while streamflow and its chloride load was calculated from the observation period listed in Table 2).

\begin{tabular}{|c|c|c|c|c|c|c|c|c|}
\hline Catchments & Gauge ID & $\begin{array}{l}\text { Precipitation } \\
\mathrm{mm} \mathrm{yr}^{-1}\end{array}$ & $\begin{array}{l}\text { Streamflow } \\
\mathrm{mm} \mathrm{yr}^{-1}\end{array}$ & $\begin{array}{l}\text { Water O/I } \\
\mathrm{g} \mathrm{m}^{-2} \mathrm{yr}^{-1}\end{array}$ & $\begin{array}{l}\text { Cl deposition } \\
\mathrm{g} \mathrm{m}^{-2} \mathrm{yr}^{-1}\end{array}$ & Stream Cl load & $\mathrm{ClO} / \mathrm{I}$ & $\begin{array}{l}\text { Chloride } \\
\text { equilibrium types }\end{array}$ \\
\hline 1. Bremer at U/S & 4260688 & 574 & 16 & 0.03 & 3.7 & 14.9 & 4.1 & VI \\
\hline 2. Western Flat Creek & 4261018 & 768 & 22 & 0.03 & 4.3 & 9.8 & 2.3 & VI \\
\hline 3. Bremer at Bletchley & 4261070 & 610 & 5 & 0.01 & 4.1 & 2.2 & 0.5 & $\mathrm{~V}$ \\
\hline 4. Finniss River & 4261075 & 802 & 61 & 0.08 & 5.2 & 11.2 & 2.2 & VI \\
\hline 5. Currency Creek & 4261099 & 710 & 59 & 0.08 & 6.1 & 21.3 & 3.5 & VI \\
\hline 6. Giles Creek & 4261103 & 607 & 27 & 0.04 & 5.5 & 17.2 & 3.1 & VI \\
\hline 7. Onkaparinga at Houlgrave & 5030504 & 871 & 279 & 0.32 & 4.4 & 30.9 & 7.1 & III \\
\hline 8. Onkaparinga at Hahndorf & 5030537 & 838 & 8 & 0.01 & 4.2 & 1.9 & 0.5 & I or II \\
\hline 9. Pedler Creek & 5030543 & 736 & 16 & 0.02 & 5.0 & 2.2 & 0.4 & IV \\
\hline 10. Torrens River at Mt. Pleasant & 5040512 & 813 & 8 & 0.01 & 3.2 & 6.4 & 2.0 & VI \\
\hline 11. North Para River at Mt. McKenzie & 5050533 & 723 & 168 & 0.23 & 3.1 & 97.7 & 31.4 & IV and VI \\
\hline
\end{tabular}

this catchment can be regarded as a type I catchment. This is supported by the low water $\mathrm{O} / \mathrm{I}$ ratio (Table 3 ). For catchment 9 , it is difficult to determine the chloride equilibrium condition solely from the chloride $\mathrm{O} / \mathrm{I}$ ratio. The stream is ephemeral, only flowing three to four months during raining seasons. Chloride concentrations in stream water are below $400 \mathrm{mg} \mathrm{l}^{-1}$ (not shown). The incorporation of climate conditions in the determination of the chloride equilibrium status of catchment 9 is discussed in the next section.

\subsection{Chloride equilibrium status in relation to precipitation}

For the six type VI catchments (Table 3), correlations between chloride $\mathrm{O} / \mathrm{I}$ and climate (precipitation), hydrology (water O/I, streamflow), and catchment geometry (area, elevation, and slope) variables were determined (Fig. 7). Of the six variables, only mean annual precipitation is significantly correlated with chloride $\mathrm{O} / \mathrm{I}$ ratio, with a Pearson correlation coefficient of 0.89 . This correlation is statistically significant at a confidence level of $98 \%(p$ value $=0.017)$. The high correlation between chloride $\mathrm{O} / \mathrm{I}$ and precipitation supports the assumption that aquifer properties do not account for catchment chloride $\mathrm{O} / \mathrm{I}$ variability in the study area. Regression of chloride $\mathrm{O} / \mathrm{I}$ ratios on mean annual precipitation for the six type VI catchments (Fig. 8a suggests that the chloride O/I ratio decreases with annual precipitation, which is consistent with the conceptual model shown in Fig. 5. For comparison, plots of cumulative stream chloride load vs. cumulative streamflow (Fig. 8b) show that stream chloride concentration inferred from slopes of the curves generally decrease with annual precipitation for the six type VI catchments. If a chloride $\mathrm{O} / \mathrm{I}$ ratio of one approximates a new chloride equilibrium condition then a catchment with annual precipitation of $960 \mathrm{~mm}$ has by now reached a new equilibrium. As the forest clearance occurred in the MLR area 100-150 years ago, this regression result indicates that it takes less than 100-150 years for a catchment of $960 \mathrm{~mm}$ annual rainfall to reach a new chloride equilibrium.

These results suggest that in the MLR area, catchments having an annual precipitation larger than $960 \mathrm{~mm}$ had reached a new chloride equilibrium by 2008 , when stream data were collected. A catchment having annual precipitation much smaller than $960 \mathrm{~mm}$ is still in chloride disequilibrium, because the chloride $\mathrm{O} / \mathrm{I}$ ratio predicted using the regression function in Fig. 8a is larger than one. This is consistent with earlier discussion regarding chloride equilibrium status of catchments 1 (type VI, annual precipitation $574 \mathrm{~mm}$ ), 2 (VI, $768 \mathrm{~mm}$ ), 3 (V, $610 \mathrm{~mm}), 4$ (VI, $802 \mathrm{~mm}), 5$ (VI, $710 \mathrm{~mm}), 6$ (VI, $610 \mathrm{~mm}$ ), and 10 (VI, $813 \mathrm{~mm}$ ) (Table 3). According to this annual precipitation threshold, Pedler Creek (catchment 9, annual precipitation $736 \mathrm{~mm}$ ) is in chloride disequilibrium and is currently a type $\mathrm{V}$ catchment. As the threshold of $960 \mathrm{~mm}$ annual precipitation was derived from type VI catchments, it accounts for the time required to transport historical chloride in the vadose zone and in shallow groundwater into the stream. It is likely that a catchment with an annual precipitation slightly below $960 \mathrm{~mm}$ has reached a new equilibrium. The Onkaparinga at Hahndorf (catchment 8, $838 \mathrm{~mm}$ ) is one such example. The Onkaparinga at Houlgrave (catchment $7,871 \mathrm{~mm}$ ) should have reached new chloride equilibrium, supporting the earlier conclusion that it is a type III catchment. In summary, a catchment in the MLR area having an annual precipitation around $900 \mathrm{~mm}$ has most likely reached new chloride equilibrium.

\subsection{CMB method estimated groundwater recharge}

Out of eleven examined catchments, two (catchment 7 , which receives Murray River water and catchment 8) have most likely reached a new chloride equilibrium, and are valid for the CMB application. To avoid the complexity introduced by cross-catchment water input, the CMB estimation was performed for catchment 8 only. As most groundwater 

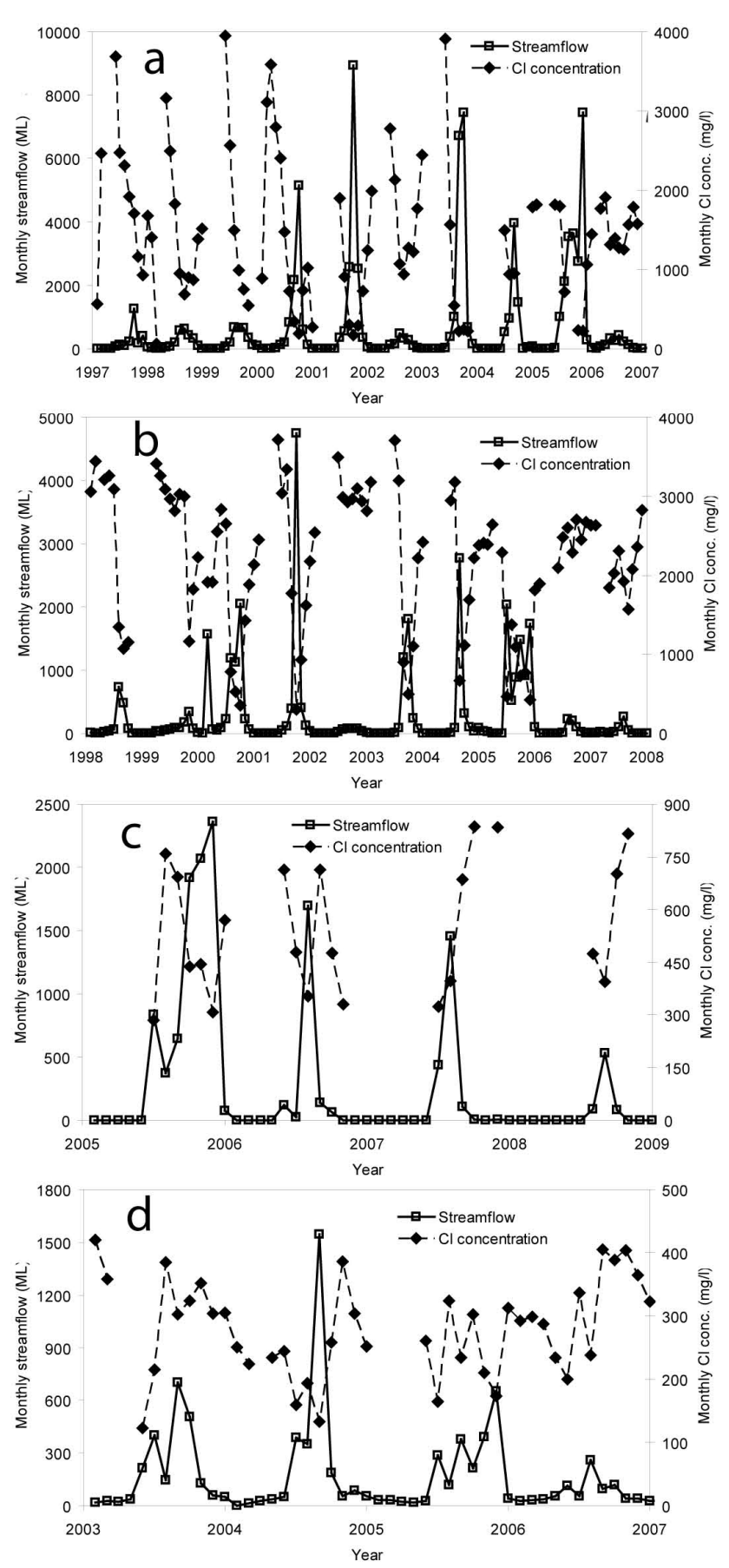

Fig. 6. Monthly series of streamflow and water-weighted average monthly chloride concentration in stream water for four selected catchments: (a) North Para River catchment with gauge ID 5050533, (b) Bremer catchment with gauge ID 4260688, (c) Bremer catchment with gauge ID 4261070, and (d) Onkaparinga at Hahndorf catchment with gauge ID 5030537.

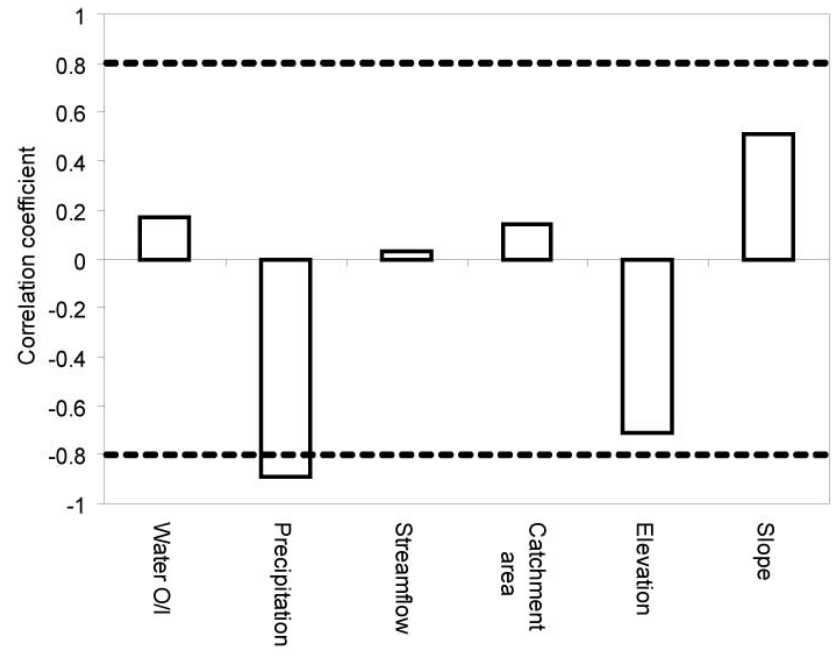

Fig. 7. Pearson correlation coefficient between chloride $\mathrm{O} / \mathrm{I}$ and each of the six selected climate and catchment variables for all type VI catchments (Table 3). The dash lines are statistically significant linear correlation at $95 \%$ confidence level, showing that only precipitation is significantly correlated to chloride $\mathrm{O} / \mathrm{I}$ ratios.

samples over this catchment (Fig. 3) are depth averaged samples, they are not appropriate for calculating recent groundwater recharge using the CMB approach. Three approaches are applied to estimate the mean chloride concentration in recent net water-table recharge. First, the chloride concentration is assumed larger during the non-equilibrium period than in the new equilibrium period. Only data points to the left of the mode $\left(125 \mathrm{mg}^{-1}\right)$ in the histogram of chloride concentration data were used to estimate average chloride concentration (Fig. 9a). Some samples having a chloride concentration below $10 \mathrm{mg}^{-1}$, similar to bulk precipitation chloride concentration (about $5 \mathrm{mg}^{-1}$ ) were excluded. Second, both tritium data and chloride concentration were used to define data points likely to represent the new chloride equilibrium (Fig. 9b). The data points on the upper-left corner of the plot, having a low chloride concentration and high tritium units, were selected. One sample without tritium data, with a chloride concentration below $50 \mathrm{mg}^{-1}$, was included in the calculation. Third, principal component analysis was used to identify the data points of the new chloride equilibrium. Principal component analysis of major ion concentration data from a nearby catchment indicates that the second principal component is often related to transient processes after vegetation clearance (Ding et al., 2010). Thus, a small score for this principal component indicates a new chloride equilibrium. The samples with near-zero principal component scores are regarded as recent groundwater recharge (Fig. 9c). After these data points are determined, their geometric mean is calculated. The estimated mean groundwater chloride concentrations at the new equilibrium are 76,96 , and $89 \mathrm{mg} \mathrm{l}^{-1}$ from the three methods, respectively. 

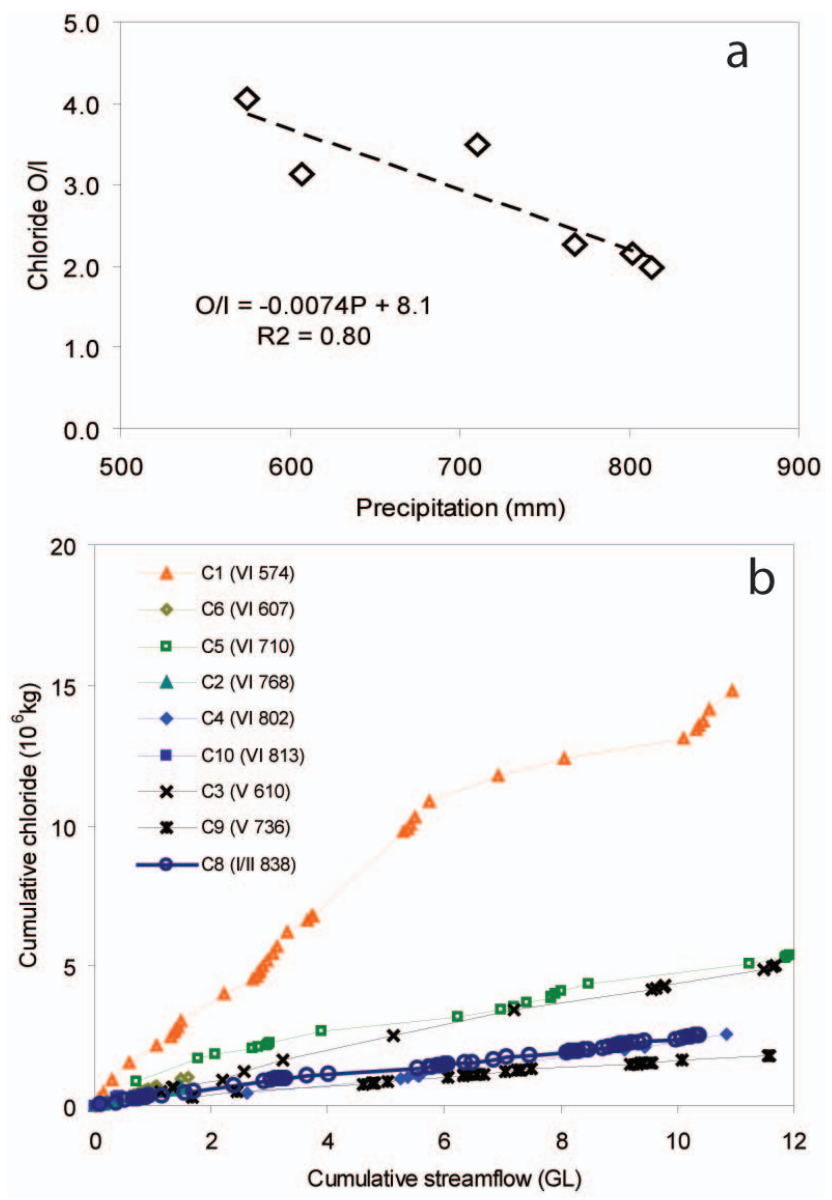

Fig. 8. (a) Catchment chloride ratio vs. catchment average annual precipitation for all type VI catchments, indicating that a catchment of an average precipitation of $960 \mathrm{~mm} . \mathrm{yr}^{-1}$ would have now (2008) reached the new chloride equilibrium (type II). (b) Cumulative chloride load in the stream water vs. cumulative streamflow for six type VI catchments, showing that the average chloride concentration (the slope of the curve) decreases with increasing annual precipitation (the number in the legend), with two type $\mathrm{V}$ catchments and one chloride equilibrium catchment for comparison.

If an average chloride concentration of $85 \mathrm{mg} \mathrm{l}^{-1}$ is used for currently recharged groundwater, the net catchment recharge is estimated to be $27 \mathrm{~mm} /$ year, about $3 \%$ of annual precipitation. The uncertainty of this estimate originates from estimates of catchment chloride deposition as well as average chloride concentration of the recent recharge. The former is estimated to be about $20 \%$ at a $90 \%$ confidence level (Guan et al., 2010). For the latter source of uncertainty, if three estimates $\left(76,96\right.$, and $\left.89 \mathrm{mg}^{-1}\right)$ are assumed from a normal distribution, the uncertainty from the catchment chloride concentration estimates is less than $20 \%$ at a $90 \%$ confidence level.
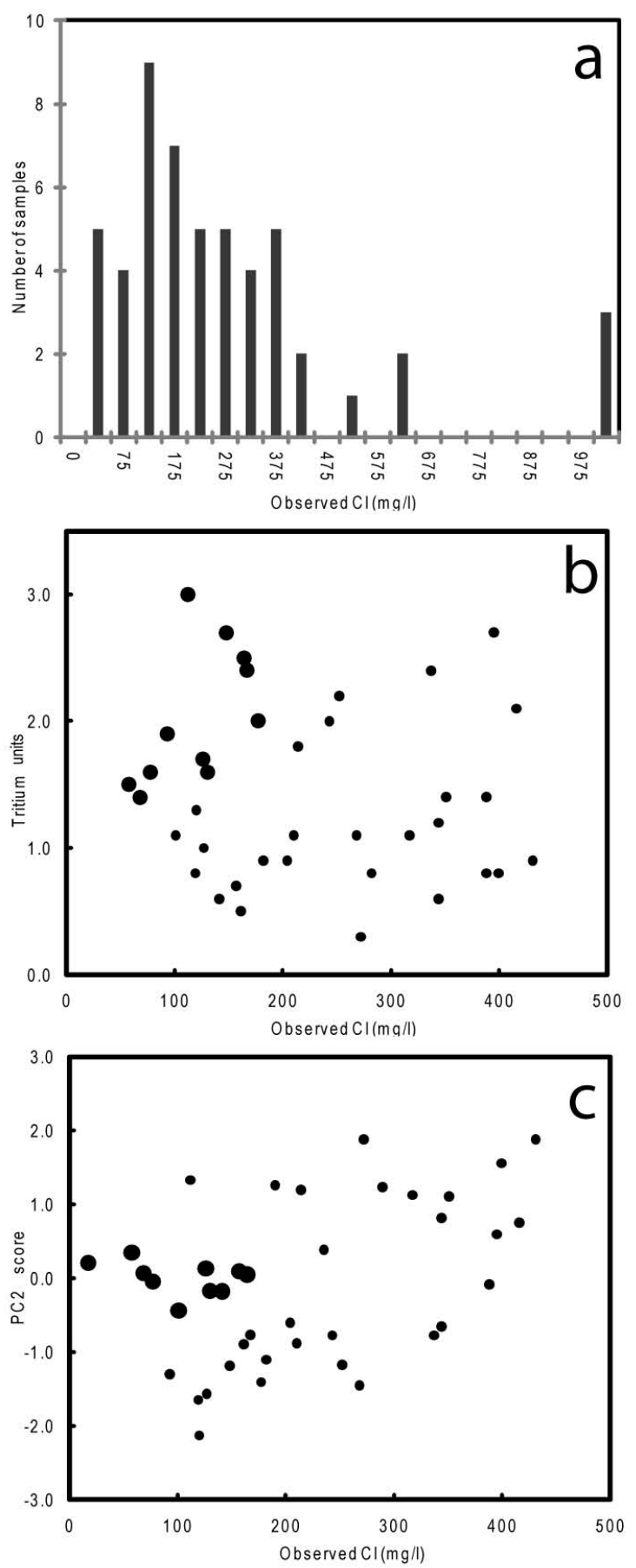

Fig. 9. Three methods to estimate average chloride concentration of recent net water-table recharge for catchment 8: (a) histogram of observed groundwater chloride concentration data, (b) tritium vs. groundwater chloride concentration, and (c) the score of second principal component (PC2) of the concentration data of eight major ions, vs. sample chloride concentration. In (a), data points to the left of the mode $\left(125 \mathrm{mg} \mathrm{l}^{-1}\right)$ are selected to calculate the geometric mean, with a few concentration data below $10 \mathrm{mg} \mathrm{l}^{-1}$ are excluded. In (b) and (c), the data points marked with the larger symbols are chosen. 


\section{Conclusions}

To examine the CMB applicability for groundwater recharge estimates in the MLR, an area having experienced widespread historical vegetation clearance, the catchment chloride budget was investigated based on a recently constructed atmospheric chloride deposition map. Six conceptual catchments representing various chloride equilibrium levels were defined, based on conditions that might be encountered in the MLR region. The conceptual models were applied to eleven selected catchments of various sizes and climate conditions. The results show that six of the eleven catchments match type VI chloride equilibrium condition (chloride disequilibrium with a gaining stream), with catchment chloride $\mathrm{O} / \mathrm{I}$ ratios ranging from 2 to 4 . Two catchments match a type $\mathrm{V}$ chloride equilibrium condition (chloride disequilibrium with a losing stream) with catchment chloride $\mathrm{O} / \mathrm{I}$ ratios of about 0.5 . For these catchments, the CMB method is not appropriate. The results also suggest that neither a chloride $\mathrm{O} / \mathrm{I}$ ratio less than one nor a low fluctuation of streamflow chloride concentration (a factor below 4) guarantees a chloride equilibrium condition. A large chloride $\mathrm{O} / \mathrm{I}$ ratio (above one) and a large fluctuation of streamflow chloride concentration fluctuation (a factor of 10 and above) generally indicate either chloride disequilibrium or cross-catchment water transfer, or both, for which CMB is not applicable. Based on the regression between chloride $\mathrm{O} / \mathrm{I}$ ratios and annual precipitation of type VI catchments, a catchment with annual precipitation around $900 \mathrm{~mm}$ in the MLR has most likely reached new chloride equilibrium, for which the CMB can be applied assuming that no cross-catchment water transfer occurs. The CMB was applied to one catchment at chloride equilibrium, resulting in an estimate of net catchment groundwater recharge of $27 \mathrm{~mm}$, or about $3 \%$ of annual precipitation.

Acknowledgements. Discussion with Peter Cook and Ian Jolly is appreciated. Graham Green from the Department of Water, Land and Biodiversity Conservation of South Australia provided streamflow and EC data. Peter Goonan from the Environmental Protection Authority of South Australia provided stream water chemistry data.

Edited by: J. Carrera

\section{References}

Birkeland, P. W.: Soils and Geomorphology. Oxford University Press, New York, 430 pp., 1999.

Cook, P. G., Edmunds, W. M., and Gaye, C. B.: Estimating paleorecharge and paleoclimate from unsaturated zone profiles. Water Resour. Res., 28(10), 2721-2731, 1992.

Cook, P. G., Walker, G. R., and Jolly, I. D.: Spatial variability of groundwater recharge in a semiarid region, J. Hydrol., 111(1-4), 195-212, 1989.
Dawes, W. R., Gilfedder, M., Walker, G. R., and Evans, W. R.: Biophysical modelling of catchment-scale surface water and groundwater response to land-use change, Math. Comput. Simul., 64(1), 3-12, 2004.

Dettinger, M. D.: Reconnaissance estimates of natural recharge to desert basins in Neveda, USA, by using chloride-balance calculations, J. Hydrol., 106(1-2), 55-78, 1989.

Ding, Z., Guan, H., Hutson, J., Love, A. J., and Simmons, C. T.: Examination of forest clearance induced dynamic hydrochemical response using principal component analysis, J. Hydrol., in review, 2010.

Dingman, S. L.: Physical Hydrology. Prentice-Hall, Inc., 575 pp., 1994.

Edmunds, W. M., Fellman, E., Goni, I. B., and Prudhomme, C.: Spatial and temporal distribution of groundwater recharge in northern Nigeria, Hydrogeol. J., 10(1), 205-215, 2002.

Eriksson, E. and Khunakasem, V.: Chloride concentrations in groundwater, recharge rate and rate of deposition of chloride in the Israel coastal plain, J. Hydrol., 7, 178-197, 1969.

Flint, A. L., Flint, L. E., Kwicklis, E. M., Fabryka-Martin, J. T., and Bodvarsson, G. S.: Estimating recharge at Yucca Mountain, Nevada, USA: comparison of methods, Hydrogeol. J., 10, 180204, 2002.

Gilfedder, M., Walker, G. R., Dawes, W. R., and Stenson, M. P.: Prioritisation approach for estimating the biophysical impacts of land-use change on stream flow and salt export at a catchment scale, Environ. Modell. Softw., 24, 262-269, 2009.

Glanznig, A.: Native vegetation clearance, habitat loss and biodiversity decline, Australian Government Department of the Environment, Water, Heritage and the Arts, 1995.

Green, G., Banks, E., Wilson, T., and Love, A.: Groundwater recharge and flow investigations in the Western Mount Lofty Ranges, South Australia, Adelaide, 2007.

Guan, H., Simmons, C. T. and Love, A. J.: Orographic controls on rain water isotope distribution in the Mount Lofty Ranges of South Australia, J. Hydrol., 372, 255-264, doi:10.1016/j.jhydrol 2009.06.018, 2009.

Guan, H., Love, A. J., Simmons, C. T. and Kayaalp, A. S.: Factors influencing chloride deposition in a coastal hilly area and application to chloride deposition mapping, Hydrol. Earth Syst. Sci., accepted, 2010.

Jolly, I., Walker, G., Stace, P., Van der Wel, B., and Leaney, R.: Assessing the impacts of dryland salinity on South Australia's water resources 9/00, CSIRO Land and Water, Adelaide, Australia, 2000.

Jolly, I. D., Williamson, D. R., Gilfedder, M., et al.: Historical stream salinity trends and catchment salt balances in the MurrayDarling Basin, Australia, Mar. Freshw. Res., 52(1), 53-63, 2001.

Kayaalp, A. S.: Application of rainfall chemistry and isotope data to hydro-meteorological modelling, Ph.D. Thesis, Flinders University, Adelaide, Australia, 273 pp., 2001.

Kayaalp, A. S. and Bye, J. A. T.: The water and salt balance of the reservoir catchments of the Mount Lofty Ranges, South Australia, Trans. R. Soc. S. Aust., 127, 15-26, 2003.

Likens, G. E., Bonnann, F. H., Pierce, R. S., and Reiner, W. A.: Recovery of a deforested ecosystem, Science, 199, 492-496, 1978.

Ma, J. Z., Ding, Z. Y., Edmunds, W. M., Gates, J. B. and Huang, T. M.: Limits to recharge of groundwater from Tibetan plateau to the Gobi desert, implications for water management in the moun- 
tain front, J. Hydrol., 364(1-2), 128-141, 2009.

Meinzer, O. E.: Outline of ground-water hydrology with definitions. U.S. Geological Survey Water Supply Paper 494, 1923.

Peck, A. J. and Hatton, T.: Salinity and the discharge of salts from catchments in Australia, J. Hydrol., 272(1-4), 191-202, 2003.

Peck, A. J. and Hurle, D. H.: Chloride balance of some farmed and forested catchments in southwestern Australia, Water Resour. Res., 9(3), 648-657, 1973.

Petheram, C., Walker, G., Grayson, R., Thierfelder, T. and Zhang, L.: Towards a framework for predicting impacts of land-use on recharge: 1. A review of recharge studies in Australia. Australian Journal of Soil Research, 40(??), 397-417, 2002.

Phillips, F. M.: Environmental tracers for water movement in desert soils of the American southwest, Soil Sci. Soc. Am. J., 58(1), 15-24, 1994.

Poulsen, D. L., Simmons, C. T., La Salle, C. L., and Cox, J. W.: Assessing catchment-scale spatial and temporal patterns of groundwater and stream salinity. Hydrogeol. J., 14(7), 13391359, 2006.

Preiss, W. V.: The Adelaide Geosyncline: Late proterozoic stratigraphy, sedimentation, palaeontology and tectonics, Bulletin/Geological Survey of South Australia, 53, p. 439, 1987.

Radke, B. M., Ivkovic, K. M., Watkins, K. L., Cresswell, R. G., and Bauld, J.: A groundwater quality assessment of the upper Onkaparinga Region, Southern Mt Lofty Ranges, South Australia, 107 pp., 2000.

Scanlon, B. R. and Goldsmith, R. S.: Field study of spatial variability in unsaturated flow beneath and adjacent to playas. Water Resour. Res., 33(10), 2239-2252, 1997.

Scanlon, B. R., Healy, R. W., and Cook, P. G.: Choosing appropriate techniques for quantifying groundwater recharge, Hydrogeol. J., 10(1), 18-39, 2002.

Sivapalan, M., Ruprecht, J. K. and Viney, N. R.: Water and salt balance modelling to predict the effects of land-use changes in forested catchments .1. Small catchment water balance model, Hydrol. Proc., 10(3): 393-411, 1996.
Smitt, C., Gilfedder, M., Dawes, W., Petheram, C., and Walker, G.: Modelling the Effectiveness of Recharge Reduction for Salinity Managment: Sensitivity to Catchment Characteristics, Canberra, Australia, 16 pp., 2003.

Wahi, A. K., Hogan, J. F., Ekwurzel, B., Baillie, M. N., and Eastoe, C.J.: Geochemical quantification of semiarid mountain recharge, Ground Water, 46(3), 414-425, 2008.

Walker, G. R., Jolley, I. D., and Cook, P. G.: A new chloride leaching approach to the estimation of diffuse recharge following a change in land use, J. Hydrol., 128, 49-67, 1991.

White, I., Macdonald, B. C. T., Somerville, P. D., and Wasson, R.: Evaluation of salt sources and loads in the upland areas of the Murray-Darling Basin, Australia, Hydrol. Process., 23(17), 2485-2495, 2009.

Williamson, D. R., Stokes, R. A. and Ruprecht, J. K.: Response of input and output of water and chloride to clearing for agriculture, J. Hydrol., 94(1-2), 1-28, 1987.

Williamson, D. R. and van de Wel, B.: Quantification of the impact of dryland salinity on water resources in the Mt Lofty Ranges, SA, The Institution of Engineers Australia, Perth, Australia, 48$52,1991$.

Wilson, J.L. and Guan, H.: Mountain-block hydrology and mountain-front recharge, in: Groundwater Recharge in a Desert Environment: The Southwestern United States, edited by: J. F. Hogan, Phillips, F. M., and Scanlon, B. R., Water Science and Applications Series, American Geophysical Union, Washington, DC, USA, 113-137, 2004.

Wood, W. W.: Use and misuse of the chloride-mass balance method in estimating ground water recharge, Ground Water, 37(1), 2-3, 1999.

Wood, W. W. and Sanford, W. E.: Chemical and isotopic methods for quantifying groundwater recharge in a regional, semiarid environment, Ground Water, 33(3), 458-468, 1995. 